\title{
Effect of Packaging Materiales, Storage Conditions, Cultivar and Extraction Methods on The Extraction Quality of Roselle Calyxes
}

\author{
Gomaa, R. B. A. ${ }^{1}$, and M.M. Rashed Nahed ${ }^{2}$
}

\begin{abstract}
Effect of packaging materiales, extraction methods and storage period on some quality of two cultivars of Roselle calyxes extracts has been studied. Dark red and light red Roselle calyxes packed in- low density polyethylene (LDPE) and Glass bottles and stored for eight months at room temperature. Two methods were carried out for preparation of Roselle extract from both dark and light cultivars. Soaking in distilled water or acidic water $(\mathbf{2 \%}$ citric acid) at different temperatures $\left(5,20,60\right.$ and $\left.100{ }^{\circ} \mathrm{C}\right)$ for several periods $(1 / 2: 24 \mathrm{hrs})$. The packaging type, cultivars of Roselle, extraction method soaking temperature, soaking period and storage period were highly significant effect for TSS, and anthocyanin, but there are no significant different in $\mathrm{pH}$ value with packaging type or extraction method. T.S.S. content was found to be increased by increasing soaking temperature, soaking period and storage period for both dark and light cultivars packed in (LDPE and Glass bottles) and soaked in distilled water or acidic water ( $2 \%$ citric acid). High total soluble solids content was recorded for dark red cultivar packed in low density polyethylene (LDPE) and extracted with acidic water $\left(2 \%\right.$ citric acid) at $100{ }^{\circ} \mathrm{C}$ for $90 \mathrm{~min}$. The PH values of Roselle calyxes extract was found to be depending on soaking temperature, soaking period and storge time.The $\mathrm{pH}$ value of light Roselle calyxes extract was less than that of dark red Roselle calyxes extract with all treatments. High decreament in $\mathrm{pH}$ value of Roselle calyxes extract was recorded for light red cultivar packed in glass bottle and extracted with acidic water ( $2 \%$ citric acid) at $100{ }^{\circ} \mathrm{C}$ for $90 \mathrm{~min}$. Anthocyanin value increased in Roselle calyxes extracts of both dark and light cultivars with increasing soaking temperature and soaking period in both water or acidic water ( $2 \%$ citric acid) but decreased with increasing storage period.
\end{abstract}

\section{INTRODUCTION}

Roselle (Hibiscus subdariffa L.) is a tropical plant which belongs to the family Malvaceae. It is an annual herb cultivated for its leaves, stem, seed and calyxes (Umerchuruba,1997). Roselle produces red edible calyxes which primarily can be used for making brilliant red color jam, jelly, preserve and juice. (Hirunpanish et al., 2006).

Since the early 1970s, roselle has received great considerable attention as a potential source of natural food colorant, pharmaceuticals and cosmetics (Mazza and Miniati, 1993). Currently, roselle is also claimed as a Thai traditional medicine for kidney stones and can be used as antibacterial and antifungal substances (Farnworth and Bunyapraphatsara, 1992). chemical and mineral composition of the calyces of green, red and dark red roselle were evaluated. There was no significant difference in crude protein of green(17.9\%) and red $(17.4 \%)$ coloured roselle calyces. Crude fiber $(11.2 \%)$, ascorbic acid $(86.5 \mathrm{mg} / 100 \mathrm{~g})$ and sodium $(9.5 \mathrm{mg} / 100 \mathrm{~g})$ contents of green coloured calyx were significantly higher than other calyx samples. However, dark red calyx was significantly higher in ash $(6.8 \%)$ and potassium $(2320 \mathrm{mg} / 100 \mathrm{~g})$ contents than the other two calyces. Also, there was no significant differences in calcium, magnesium and zinc contents of red and dark red coloured roselle calyces. Roselle calyces appeared to be cheap source of vegetable protein and minerals therefore its consumption should be encouraged. Babalola, et al (2000).

The physico-chemical characteristics of Roselle were studied and it was characterized as a highly acidic fruit with low sugar content. Succinic acid and oxalic acid were quantified as two predominant organic acids in Roselle. Roselle was found to contain higher amount of ascorbic acid compared to orange and mango( Wong et al., 2002).

Roselle anthocyanin's can also contribute to benefit for health as a good source of antioxidants as well as a natural food colourant.The reactions usually involve decolorization of the anthocyanin pigments. The rate of anthocyanin destruction depends on many factors such as $\mathrm{pH}$, temperature, intermolecular copigmentation, ascorbic acid, oxygen, etc. The reactions are usually undesirable in juice processing and long-term product storage (Al-kahtani and Hassan,1990).

Roselle-fruit flavored drinks were prepared from dried calyces of Hibiscus sabdariffa. $\mathrm{pH}$ decreased while titratable acidity increased with time for samples at ambient and refrigeration conditions. While microbial load of samples at ambient and refrigeration increased with time, those of samples at freezing condition decreased. Samples at ambient storage had a shelf-life of less of than five days while those at refrigeration condition stored for about a week and the samples at

1-Food Tech. Res. Inst., Agric. Res. Center, Giza, Egypt.,

${ }^{2-}$ Department Medicinal and Aromatic Plants,

Agricultural Research Center, Dokki, Giza. Egypt.

Received April 3, 2011, Accepted May31, 2011 
freezing condition could store for more than two weeks (Fasoyiro et al,2005).

The dried calyces/water ratios involved in the commercial practice ranged between 1:57 and 1:71 $(w / v)$ while the sweetness were found to be colour intensity, sweetness level and pleasant taste. The appropriate dried calyces/water ratio for commercial soborodo production was found to be $1: 62(\mathrm{w} / \mathrm{v})$ while the extraction period was 30 minutes at a constant temperature of $100^{\circ} \pm 2^{\circ} \mathrm{C}$. The appropriate sweetness level was found to be $13 \%$ sugar inclusion.(Bold.et $a l, 2009)$

Physical and chemical properties of fresh Roselle calyxes and optimum conditions for water extraction of Roselle were studied For dried Roselle calyxes, the optimum conditions were 1:10 ratio of dried calyxes to water and the extraction temperature of $50{ }^{\circ} \mathrm{C}$ for 30 min. The $\mathrm{pH}$, total acidity and total soluble solids contents of concentrated dried Roselle extract were $2.89 \pm 0.05,11.96 \pm 0.34 \%$ as malic acid and $25.07 \pm 0.10$ oBrix. The total anthocyanin, total phenolic contents and EC50 were $340.97 \pm 0.15 \mathrm{mg} / 100 \mathrm{~g}$ dried Roselle calyxes, $31.18 \pm 0.62 \mathrm{mg}$ gallic acid/g and $47.53 \pm 0.85$ $\mathrm{mg} / \mathrm{ml}(\mathrm{n}=9)$, respectively.(Chumsri, et al,2008).

Therefore, the objective of this work was to: (a) study the physical and chemical properties two cultivars of Roselle calyxes (b) Study the effect of packaging materials [lowdensity polyethylene (LDPE) and glass bottle] of the quality of the samples. (c) Study the optimum conditions for water extraction of Roselle, to prolonging the shelf life and preserving the quality of both dark and light red Roselle calyxes when stored at room temperature for eight months.

\section{MATERIALS AND METHODS}

\section{Materials}

\section{- Source of Roselle calyxes (Hibiscus subdariffa L.):}

This investigation was consummated during the two successive seasons of 2008 and 2009, at the lab in the Food Technology Dept., Agriculture Research Center, at Sakha, Kafr El-Sheikh Governorate, Egypt. Seeds of the two cultivars of Roselle calyxes (Hibiscus subdariffa L.), dark red roselle and light red roselle were obtained from Medicinal and Aromatic Dept., Agriculture Research Center and sown at the Experimental Farm Station of Agriculture Research Center, at Sakha , Kafr El-Sheikh Governorate, Egypt, on May for the two seasons in rows $60 \mathrm{~cm}$ a part at distance of $40 \mathrm{~cm}$ between plants and harvested at November in the two seasons. Plant samples were cut at $5 \mathrm{~cm}$ above soil surface. After harvesting, fresh dark and light red roselle calyxes were washed three times with tap water, removed their seeds and dried in a oven air dryer at $50^{\circ}$
C for 36 hours to adjust their $11 \%$ moisture content of dried roselle calyxes to determining their physical and chemical properties of the two cultivars of Roselle calyxes on zero day .Dried roselle calyxes, divided into two groups. Groups were randomly assigned to each of the treatment-combinations. After then three hundred gram each of two samples [dark and light red roselle calyxes] were packaged in low density polyethylene (LDPE). and glass bottles. Packaged roselle samples were stored at room temperature. Various quality indices along with subjective evaluation were determined during storage period up to eight months at room temperature.

- Source of packaging materials:

- low density polyethylene (LDPE thickness $30 \mu$ ). was donated from Arabic medical packaging company (Flexpack), Cairo, Egypt.

- Glass bottles are available in the Egyptian local market.

\section{- Chemicals:}

All chemicals materials used were food grade and were bought from the local market.

\section{Methods}

\section{Sample preparation:}

1.1. After harvesting, fresh dark and light red Roselle calyxes were washed with tap water three times, removed the seeds and dried in a oven air dryer at $50 \mathrm{C}^{\circ}$ for 36 hours to obtain $11 \%$ moisture content of dried roselle calyxes to determine the physical and chemical properties of the two cultivars of Roselle calyxes on zero day.

1.2. Prior to packaging, Dried Roselle calyxes, divided into two groups. Groups were randomly assigned to each of the treatment-combinations. After then three hundred gram each of two samples [ dark and light red roselle calyxes] were packed in low density polyethylene (LDPE). and glass bottles. Packed Roselle samples were stored at room temperature. Various quality indices along with subjective evaluation were determined during storage period up to eight months at room temperature.

\section{Preparation of Roselle extract:}

Thirty grams of both dark and light red Roselle were soaked in $300 \mathrm{ml}$ water or in acidic water with $2 \%$ citric acid as described by Du et al., (1975) at 5, 20, 60 and $100 \mathrm{C}^{\circ}$ for different periods from $30 \mathrm{~min}$. up to $24 \mathrm{hrs}$. The produced extracts were kept in refrigerator till measured.

\section{3. physical and chemical properties.}

3.1. Total soluble solids (T.S.S): The percentage of the average of the two seasons (2008-2009) of the total 
soluble solids content of the two cultivars of Roselle calyxes was measured by a hand refractometer according to method out lined in A.O.A.C. (2005) for all treatments after all storage periods .

3.2. The pH values: The $\mathrm{PH}$ values of the two seasons (2008-2009) of Roselle calyxes extract were measured by the use bench top $\mathrm{pH}$-meter for all treatments after all storage periods .

3.3.Total Anthocyanin Content (mg/100g): The average of the two seasons (2008-2009) of Total Anthocyanin content of the two cultivars of Roselle calyxes extract was determined colourimetrically according to the procedure described by Du and Francis (1973) for all treatments after all storage periods .

4. Statistical analysis: Statistical analysis was conducted using the SPSS Statistical Software Package (v.11.5). Comparisons among the main treatment means were made using Tukey's H.S.D at $(\mathrm{P}=0.05)$.

\section{RESULTS AND DISCUSSION}

$\mathrm{pH}$ value, TSS and Total anthocyanin content (TAC) are important properties for the quality of Roselle calyxes extracts. The low $\mathrm{pH}$ value and high TSS and TAC are indicators for the best quality. Various quality indices along with subjective evaluation were determined during storage period up to eight months at room temperature. Two methods were carried out for preparation of Roselle extract from both dark and light red cultivars. Soaking in distilled water or acidic water (2\% citric acid) at different temperatures $(5,20,60$ and 100C0) for several periods (1/2: $24 \mathrm{hrs}$.) and the following analyses have been carried out for evaluation of the prepared Roselle extract.

\section{Total soluble solids (T.S.S):}

Amount of Total soluble solids (TSS) is one of the indices that are used for controlling the period of soaking. Data in Table (1) observed that there was variation between the Total soluble solids of Roselle calyxes extracts of both dark and light red cultivars depending on the methods of extraction, packaging materials, soaking temperature, soaking period and storage period. The total soluble solids of Roselle calyxes extract were within the range of $1.8-4.2$ with soaking in water, while it was 2.2- 4.6 with soaking in acidic water ( $2 \%$ citric acid) for the two packaging materials and there was an increases in TSS by using an acidic water ( $2 \%$ citric acid).

The obtained data showed the correlation between methods of extraction, packaging materials, soaking temperature and extended time of soaking with the amount of TSS. As soaking time extended, the TSS amount increased in both water or acidic water $(2 \%$ citric acid) for the two packaging materials. Moreover, Roselle calyxes extracts stored in packaged low density polyethylene (LDPE) gave the highest significant TSS as compared with Roselle calyxes extracts packed in glass bottles for the two cultivars .Also, increasing soaking temperature, significantly increased the TSS. Moreover, the TSS was clearly increased with soaking at $100 \mathrm{C}^{0}$ for 30,60 and 90 min especially in the dark red cultivar.

Soaking at $100 \mathrm{C}^{0}$ for $30 \mathrm{~min}$ and packed in (LDPE) for two months produced only 2.8 and 2.6 T.S.S. for the dark and light red cultivars, respectively, while soaking in an acid water with the same treatment produced 3.1 and 3.0 for the dark and light red cultivars, respectively. These results may be due to the importance of using an acid water to release more quantities of soluble substances. Moreover, soaking at high temperature should eliminate the deleterious effect of microorganisms during the preparation Roselle calyxes extracts. These results are in agreement with those obtained by [Chumsri ,et al, 2008 and Bold, et al, 2009].

Higher Total Soluble Solids content was recorded for dark red cultivar packaged in low density polyethylene (LDPE) and extracted with acidic water ( $2 \%$ citric acid) at $100 \mathrm{C}^{0}$ for 90 min after 8 months of storage.

\section{The pH values:}

$\mathrm{pH}$ value is considered the one of the main factors that limit the acceptability of a given product by consumers. Data in Table (2) evident that there was a variation in $\mathrm{pH}$ of Roselle calyxes extract of both light and dark cultivars depending on packaging materials, soaking methods, e.g. soaking temperature, soaking period, extraction method and storage period.

As soaking temperature and soaking period increased from 5 to $100{ }^{\circ} \mathrm{C}, \mathrm{pH}$ value of extract decreased for the two packaging materials (LDPE and glass bottle) and the two extraction methods (water and water $2 \%$ citric acid). However, the decrease in $\mathrm{pH}$ value of extract was higher when used water $2 \%$ citric acid than water. The $\mathrm{pH}$ value of light Roselle calyxes extract was less than that of dark red Roselle calyxes extract with all Treatments. Such results are confirmed by those obtaind by Beristain et al., (1994).

Higher decrease in $\mathrm{pH}$ value of Roselle calyxes extract was recorded for the two cultivar and the two packaging materials and extraction with water and acidic water $2 \%$ citric acid at $100 \mathrm{C}^{0}$ for $90 \mathrm{~min}$ from zero day (control) to the end of storage (after 8 months) of 
Table1. Effect of packaging materials and extraction method on total soluble solids of dark and light Roselle calyxes extracts at different temperatures for various soaking time

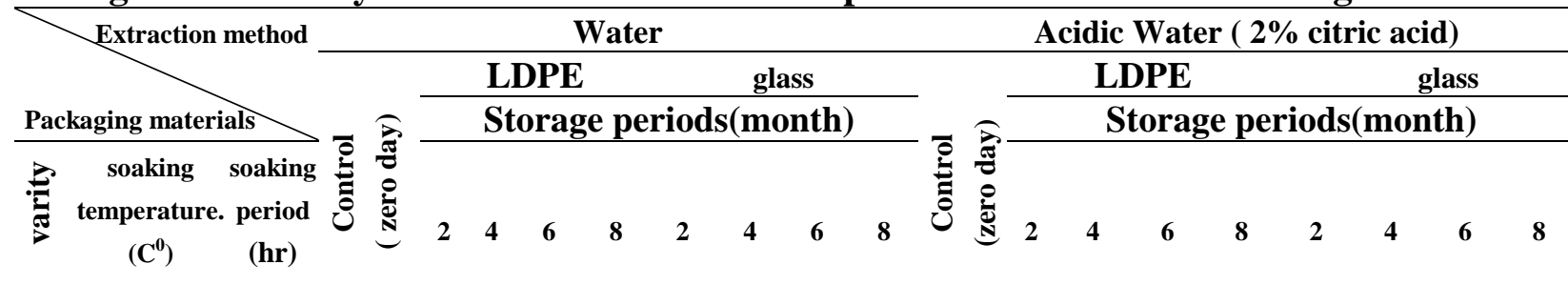

\begin{tabular}{|c|c|c|c|c|c|c|c|c|c|c|c|c|c|c|c|c|c|c|c|}
\hline \multirow{17}{*}{ 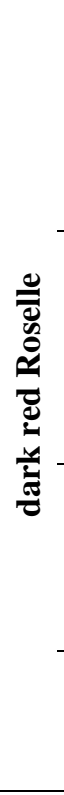 } & \multirow{5}{*}{5} & 1 & 1.8 & 2.02 .3 & 2.9 & 3.2 & 2.0 & 2.1 & 2.6 & 3.0 & 2.2 & 2.4 & 2.8 & 3.4 & 3.6 & 2.4 & 2.5 & 2.9 & 3.4 \\
\hline & & 3 & 2.0 & 2.22 .5 & 3.0 & 3.4 & 2.0 & 2.2 & 2.7 & 3.1 & 2.2 & 2.6 & 2.9 & 3.4 & 3.7 & 2.4 & 2.7 & 3.2 & 3.51 \\
\hline & & 9 & 2.0 & 2.12 .5 & 3.2 & 3.7 & 2.1 & 2.2 & 3.0 & 3.4 & 2.3 & 2.6 & 2.9 & 3.6 & 3.7 & 2.5 & 2.8 & 3.4 & 3.8 \\
\hline & & 18 & 2.3 & 2.32 .7 & 3.4 & 3.8 & 2.0 & 2.4 & 3.1 & 3.5 & 2.8 & 2.7 & 3.1 & 3.8 & 4.2 & 2.9 & 3.2 & 3.5 & 3.9 \\
\hline & & 24 & 2.4 & 2.32 .8 & 3.6 & 3.8 & 2.0 & 2.5 & 3.3 & 3.5 & 3.2 & 2.8 & 3.2 & 3.9 & 4.3 & 3.3 & 3.6 & 3.9 & 4.2 \\
\hline & \multirow{5}{*}{20} & 1 & 1.8 & 2.02 .4 & 2.9 & 3.3 & 1.8 & 2.1 & 2.6 & 3.0 & 2.2 & 2.4 & 2.8 & 3.2 & 3.7 & 2.3 & 2.4 & 3.0 & 3.2 \\
\hline & & 3 & 2.2 & 2.22 .6 & 3.3 & 3.6 & 2.0 & 2.3 & 3.0 & 3.3 & 2.6 & 2.6 & 3.1 & 3.7 & 3.9 & 2.6 & 3.0 & 3.5 & 3.4 \\
\hline & & 9 & 2.3 & 2.42 .7 & 3.6 & 3.9 & 2.1 & 2.4 & 3.3 & 3.5 & 2.7 & 2.8 & 3.2 & 3.9 & 4.3 & 2.8 & 2.9 & 3.7 & 3.9 \\
\hline & & 18 & 2.5 & 2.52 .9 & 3.8 & 3.9 & 2.2 & 2.5 & 3.5 & 3.6 & 2.9 & 2.9 & 3.3 & 4.2 & 4.4 & 3.0 & 3.2 & 3.9 & 4.0 \\
\hline & & 24 & 2.7 & 2.82 .9 & 3.9 & 4.2 & 2.5 & 2.6 & 3.6 & 4.0 & 3.1 & 3.2 & 3.4 & 4.3 & 4.6 & 3.2 & 3.3 & 4.0 & 4.4 \\
\hline & \multirow{4}{*}{60} & ${ }^{1} / 2$ & 2.3 & 2.32 .6 & 2.8 & 3.5 & 2.0 & 2.3 & 2.3 & 3.2 & 2.6 & 2.7 & 3.0 & 3.2 & 3.8 & 2.8 & 2.7 & 2.7 & 3.6 \\
\hline & & 1 & 2.6 & 2.83 .0 & 3.2 & 3.8 & 2.5 & 2.6 & 3.0 & 3.5 & 3.0 & 3.2 & 3.4 & 3.6 & 4.1 & 2.9 & 3.0 & 3.4 & 3.9 \\
\hline & & $1^{1} / 2$ & 2.7 & 2.83 .4 & 3.6 & 4.0 & 2.5 & 3.1 & 3.3 & 3.6 & 3.1 & 3.3 & 3.8 & 4.0 & 4.3 & 3.2 & 3.5 & 3.7 & 4.0 \\
\hline & & 2 & 3.2 & 3.23 .6 & 4.0 & 4.4 & 3.0 & 3.3 & 3.7 & 4.0 & 3.6 & 3.6 & 3.9 & 4.4 & 4.7 & 3.6 & 3.8 & 4.1 & 4.5 \\
\hline & \multirow{3}{*}{100} & $1 / 2$ & 2.8 & 2.83 .0 & 3.4 & 4.0 & 2.3 & 2.7 & 3.0 & 3.6 & 3.2 & 3.1 & 3.4 & 3.7 & 4.5 & 3.3 & 3.1 & 3.4 & 4.0 \\
\hline & & 1 & 3.3 & 3.53 .4 & 3.8 & 4.3 & 3.2 & 3.0 & 3.5 & 4.0 & 3.7 & 3.8 & 3.8 & 4.2 & 4.5 & 3.6 & 3.5 & 3.9 & 4.4 \\
\hline & & $1^{1} / 2$ & 3.6 & 3.63 .9 & 3.9 & 4.5 & 3.3 & 3.6 & 3.6 & 4.2 & 4.0 & 3.9 & 4.3 & 4.3 & 4.8 & 4.2 & 4.2 & 4.1 & 4.6 \\
\hline \multirow{17}{*}{ 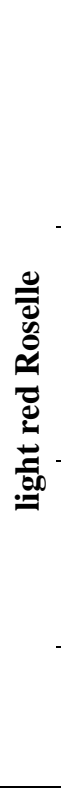 } & \multirow{5}{*}{5} & 1 & 1.8 & 1.82 .0 & 2.4 & 3.0 & 1.8 & 2.0 & 2.1 & 2.7 & 2.1 & 2.2 & 2.4 & 2.7 & 3.4 & 2.3 & 2.4 & 2.5 & 3.1 \\
\hline & & 3 & 1.8 & 1.82 .2 & 2.6 & 3.2 & 1.8 & 2.0 & 2.3 & 3.0 & 2.2 & 2.3 & 2.6 & 2.9 & 3.6 & 2.3 & 2.5 & 2.7 & 3.4 \\
\hline & & 9 & 2.0 & 2.12 .3 & 3.0 & 3.3 & 2.0 & 2.0 & 2.6 & 3.0 & 2.4 & 2.5 & 2.7 & 3.4 & 3.7 & 2.4 & 2.4 & 3.0 & 3.4 \\
\hline & & 18 & 2.0 & 2.12 .4 & 3.1 & 3.5 & 2.0 & 2.1 & 3.0 & 3.2 & 2.4 & 2.4 & 2.9 & 3.5 & 3.9 & 2.4 & 2.5 & 3.4 & 3.6 \\
\hline & & 24 & 2.2 & 2.22 .5 & 3.3 & 3.6 & 2.2 & 2.3 & 3.1 & 3.3 & 2.6 & 2.7 & 3.2 & 3.7 & 4.0 & 2.7 & 2.7 & 3.4 & 3.7 \\
\hline & \multirow{5}{*}{20} & 1 & 1.8 & 2.02 .2 & 2.6 & 3.3 & 2.0 & 2.0 & 2.3 & 3.0 & 2.2 & 2.4 & 2.7 & 2.9 & 3.5 & 2.4 & 2.4 & 2.7 & 3.4 \\
\hline & & 3 & 2.0 & 1.92 .3 & 3.0 & 3.3 & 1.8 & 2.0 & 2.8 & 3.1 & 2.4 & 2.4 & 2.8 & 3.4 & 3.8 & 2.5 & 2.5 & 3.2 & 3.5 \\
\hline & & 9 & 2.0 & 2.12 .4 & 3.3 & 3.6 & 2.0 & 2.1 & 3.0 & 3.3 & 2.3 & 2.5 & 2.8 & 3.7 & 4.0 & 2.5 & 2.6 & 3.4 & 3.7 \\
\hline & & 18 & 2.3 & 2.22 .6 & 3.5 & 3.6 & 2.2 & 2.3 & 3.2 & 3.3 & 2.7 & 2.6 & 3.0 & 3.9 & 4.0 & 2.7 & 2.8 & 3.6 & 3.7 \\
\hline & & 24 & 2.5 & 2.52 .6 & 3.6 & 4.0 & 2.5 & 2.5 & 3.2 & 3.6 & 2.9 & 2.9 & 3.1 & 4.0 & 4.4 & 2.9 & 2.9 & 3.6 & 3.9 \\
\hline & \multirow{4}{*}{60} & $1 / 2$ & 2.0 & 2.02 .3 & 2.7 & 3.3 & 2.0 & 2.0 & 2.3 & 3.0 & 2.3 & 2.4 & 2.7 & 3.1 & 3.6 & 2.4 & 2.5 & 2.7 & 3.4 \\
\hline & & 1 & 2.2 & 2.32 .7 & 2.9 & 3.5 & 2.2 & 2.6 & 2.6 & 3.2 & 2.6 & 2.7 & 3.0 & 3.3 & 3.9 & 2.6 & 3.0 & 3.2 & 3.6 \\
\hline & & $1^{1 / 2}$ & 2.5 & 2.53 .1 & 3.3 & 3.5 & 2.5 & 3.0 & 3.0 & 3.3 & 2.8 & 2.9 & 3.5 & 3.7 & 3.9 & 2.9 & 3.4 & 3.5 & 3.7 \\
\hline & & 2 & 2.5 & 2.93 .3 & 3.6 & 4.0 & 2.6 & 3.0 & 3.3 & 3.7 & 3.0 & 3.2 & 3.7 & 4.1 & 4.4 & 3.2 & 3.5 & 3.8 & 4.2 \\
\hline & \multirow[t]{3}{*}{100} & $1 / 2$ & 2.6 & 2.62 .6 & 3.1 & 3.8 & 2.5 & 2.6 & 2.8 & 3.4 & 3.2 & 3.0 & 3.0 & 3.4 & 4.2 & 3.5 & 3.6 & 3.8 & 4.0 \\
\hline & & 1 & 3.0 & 3.23 .2 & 3.5 & 4.0 & 3.0 & 3.0 & 3.2 & 3.7 & 3.5 & 3.6 & 3.8 & 4.0 & 4.5 & 3.6 & 3.5 & 4.0 & 4.3 \\
\hline & & $1^{1 / 2}$ & 3.4 & 3.53 .6 & 3.6 & 4.2 & 3.5 & 3.5 & 3.6 & 4.0 & 4.0 & 3.8 & 4.0 & 4.2 & 4.6 & 4.2 & 4.2 & 4.4 & 4.6 \\
\hline
\end{tabular}

\begin{tabular}{cccccc}
\hline treatments & varites & soaking temperature & soaking period & packaging materile extraction method storge time \\
\hline LSD $(\mathbf{0 . 0 5})$ & 0.099 & 0.105 & 0.117 & 0.074 & 0.099 \\
\hline
\end{tabular}


Table 2. Effect of packaging materials and extraction method on $\mathrm{pH}$ of dark and light Roselle calyxes extracts at different temperatures for various soaking time

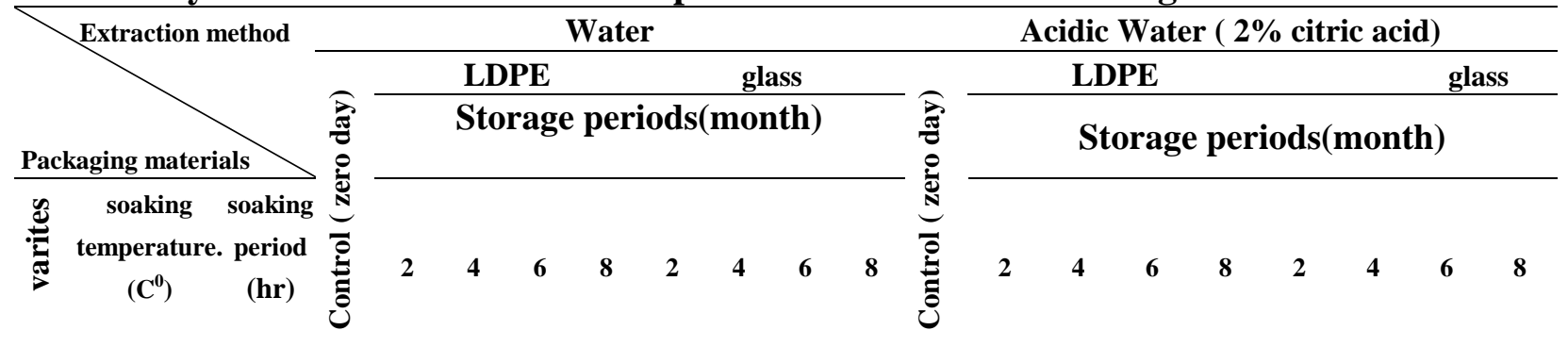

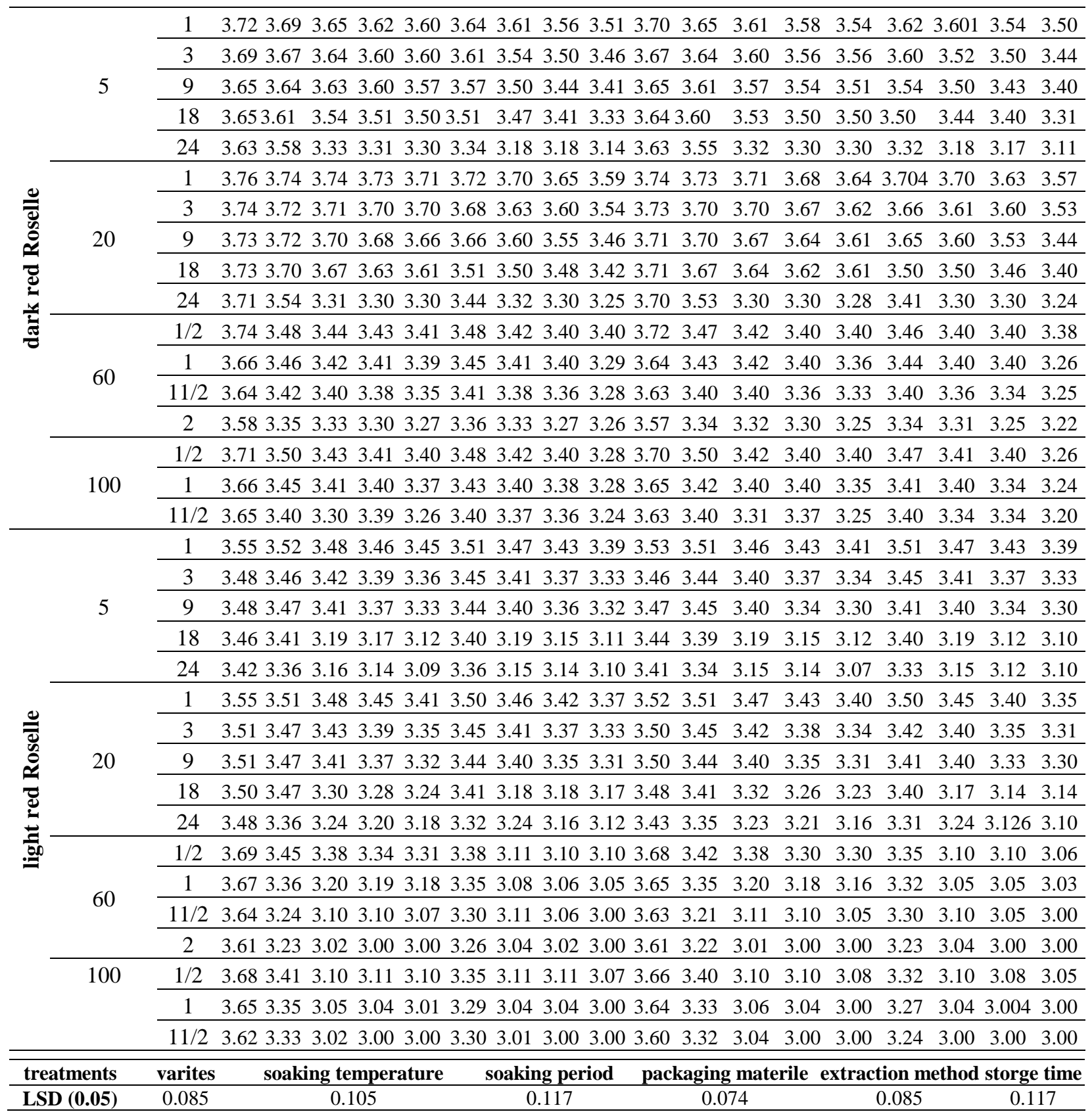


storage. The $\mathrm{pH}$ value of Roselle calyxes extract decreased from 3.62 and 3.60 to 3.00 . Wong, et al., (2002) found that the low $\mathrm{pH}$ value of the drinks was due to the acidic nature of the roselle calyces and the fruits. Roselle is characterised as a highly acidic fruit rich in organic acids: oxalic, tartaric, malic and succinic.

\section{Total Anthocyanin Content:}

Roselle calyxes are considered to be one of the excellent sources of anthocyanin. Data in Table (3) showed that the anthocyanin value $(\mathrm{mg} / 100 \mathrm{~g})$ increased in Roselle calyxes extracts of both dark and light cultivars with increasing soaking temperature and soaking period in both water or acidic water $2 \%$ citric acid and both low density polyethylene or glass bottle. The results also indicated decrease in anthocyanin content with increasing storage period.

The effect of soaking temperature on anthocyanin content $(\mathrm{mg} / 100 \mathrm{~g})$ indicated that, as soaking temperature increased, anthocyanin content increased for dark cultivar packaged in LDPE and extract in water at $5 \mathrm{C}^{0}$ for one hour recorded 35.35 , while recorded $35.35,35.71$ and 35.91 at 20,60 and $100 \mathrm{C}^{0}$ for one hour after 8 months of storage, respectively. However, anthocyanin content increased for light cultivar packed in LDPE and extract in water at $5 \mathrm{C}^{0}$ for one hour. It recorded 30.14, while recorded $30.34,30.70$ and 30.82 at 20,60 and $100 \mathrm{C}^{0}$ for one hour after 8 months of storage, respectively.

However, when used acidic water (2\% citric acid), anthocyanin content increased for dark cultivar packed in LDPE at $5 \mathrm{C}^{0}$ for one hour (27.40) while it recorded $28.00,29.00$ and 30.26 at 20,60 and $100 \mathrm{C}^{0}$ for one hour after 8 months of storage, respectively. Meanwhile, anthocyanin content increased for light cultivar packed in LDPE at $5 \mathrm{C}^{0}$ for one hour (25.34), while it 26.00,27.00 and 28.22 at 20,60 and $100 C^{0}$ for one hour after 8 months of storage, respectively.

Results indicate also that anthocyanin content were affected by methods of extraction water or acidic water $2 \%$ citric acid. Adding $2 \%$ citric acid to water caused a decrease in anthocyanin content for dark and light cultivars at all different used packaging materials, soaking temperature, soaking period and storage period . These results may be due to adding citric acid caused degradation compounds produced in these reactions and are probably quite complex. These results are in agreement with [Francis,1985and Hirunpanish et al., 2006] who reported that antioxidant activity did not have direct correlation with the amount of total anthocyanin and total phenolic contents. It may possibly be due to not only anthocyanins and phenolic compounds such as quercitin but other various constituents such as hibiscus, protocatecuic acid and Lascorbic acid also found in Roselle calyxes and contributing to Roselle antioxidant activity.

The results in Table (3) indicate also that as soaking period increased from hour to 24 hours, anthocyanin content increased, at $20 \mathrm{C}^{0}$ for one hour. Anthocyanin value recorded 32.98, while after 24 h.it recorded 34.22 with dark cultivar packaged in LDPE and extracted in water after 2 months of storage. However, with light cultivar anthocyanin value recorded 31.17 and 33.75, respectively at the same treatments. anthocyanin value ranged between $36.49-27.00$ for dark cultivar, while for light cultivar it ranged between 34.43 - 24.00. Anthocyanin value for light cultivar were lower than the dark cultivar. Similar results were reported by [Sato et al., 1991 and Chumsri.et al,2008].

\section{4. analyses of variance}

Summarizes the results of the analyses of variance and mean values of number of total soluble solids (TSS), pH and anthocyanin of two Roselle cultivars extract as affected by packaging materials, extraction method, soaking temperature, soaking period and storage period are shown in Table (4).

Refereeing to the influence of Roselle cultivars, the data clearly showed that Dark Roselle calyxes extract recorded the higher singnificant $(3.15 \%, 3.51$ and $30.33 \mathrm{mg} / 100 \mathrm{~g}$ respectively) than light Roselle calyxes extract $(2.92 \%, 3.31$ and $28.46 \mathrm{mg} / 100 \mathrm{~g}$ respectivly) for TSS, pH and anthocyanin.

For the packaging materials effect, data in table (4) included that the packaging type had the highest significant effects for TSS, and anthocyanin, but there are not significant differences with $\mathrm{pH}$. LDPE recorded the highest number than glass bottles for TSS, $\mathrm{pH}$ and anthocyanin. The extraction method were highly significant for TSS and anthocyanin, but there are no significant difference with $\mathrm{pH}$. Extraction with Water recorded the highest value as 3.418 and 29.954 for $\mathrm{pH}$ and anthocyanin, respectively. While, the extraction with acidic water $2 \%$ citric acid recorded the highest value as 3.257 for TSS.

Also, it is noticed that for total soluble solids, $\mathrm{pH}$ and anthocyanin, the main factors; e.g soaking temperature, soaking period and storage period were highly significant.

\section{CONCLUSION}

1. Dark red cultivar were higher in $\mathrm{pH}$ and Anthocyanin value while nearly to light red cultivar in total soluble solids content. 
Table 3. Effect of packaging materials and extraction method on anthocyanin of dark and light Roselle petals extracts at different temperatures for various soaking time

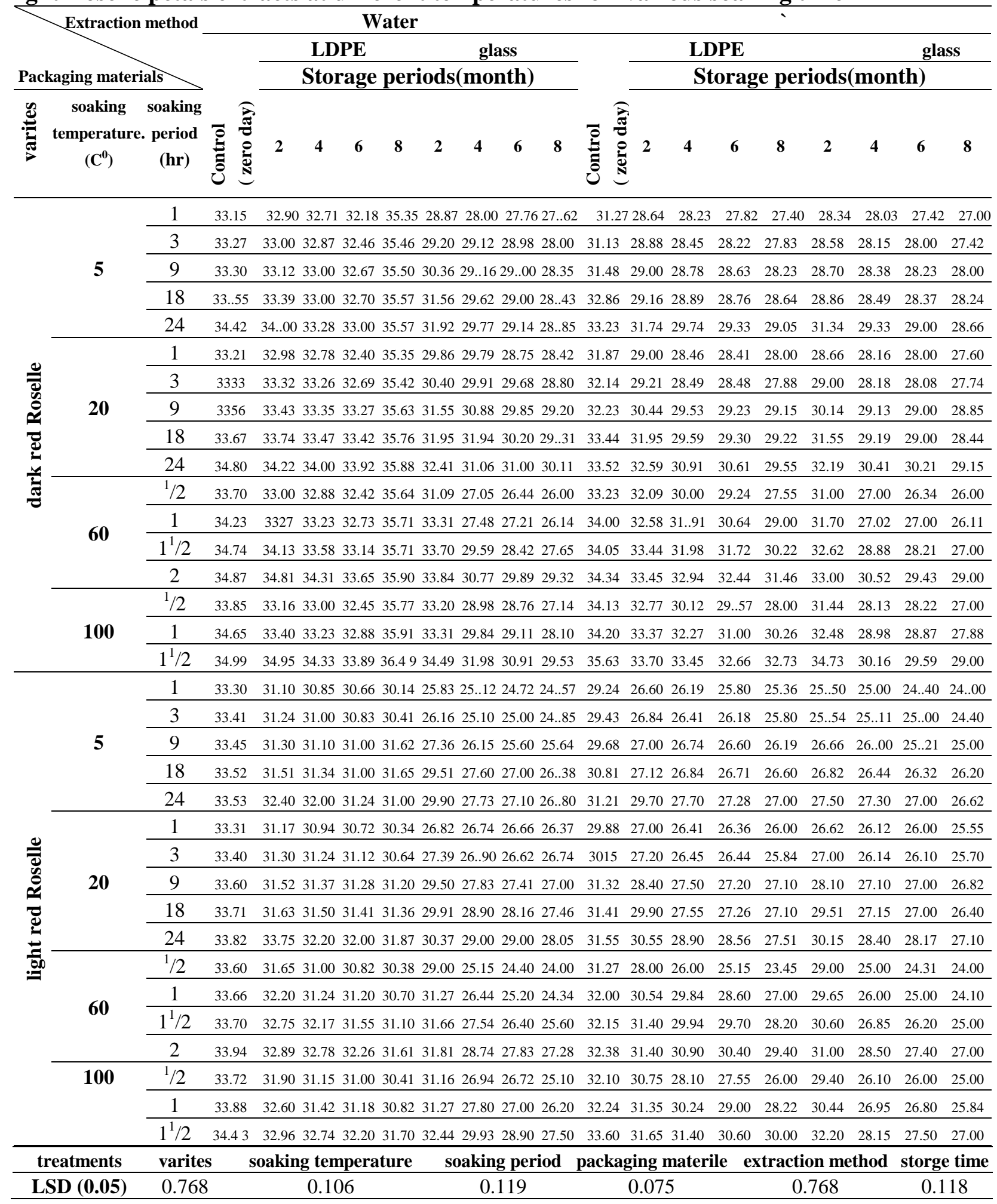


Table 4. Mean values of total soluble solids, $\mathrm{pH}$ and anthocyanin content of two Roselle cultivars extract as affected by packaging materials, extraction method, soaking temperature, soaking period and storage period

\begin{tabular}{|c|c|c|c|}
\hline Treatment & total soluble solids & pH & anthocyanin \\
\hline \multicolumn{4}{|l|}{ Cultivars } \\
\hline Dark & 3.150 & 3.508 & 30.330 \\
\hline light & 2.920 & 3.312 & 28.455 \\
\hline Sig. & $* *$ & $* *$ & $* *$ \\
\hline $\operatorname{LSD}(0.05)$ & 0.099 & 0.085 & 0.768 \\
\hline \multicolumn{4}{|l|}{ packaging materials } \\
\hline LDPE & 3.115 & 3.431 & 30.786 \\
\hline Glass bottles & 2.956 & 3.389 & 28.000 \\
\hline Sig. & $* *$ & $\mathrm{~ns}$ & $* *$ \\
\hline $\operatorname{LSD}(0.05)$ & 0.074 & 0.074 & 0.075 \\
\hline \multicolumn{4}{|l|}{ extraction method } \\
\hline Water & 2.814 & 3.418 & 29.954 \\
\hline Acidic water ( $2 \%$ citric acid) & 3.257 & 3.402 & 28.830 \\
\hline Sig. & $* *$ & ns & $* *$ \\
\hline $\operatorname{LSD}(0.05)$ & 0.099 & 0.085 & 0.768 \\
\hline \multicolumn{4}{|l|}{ soaking temperature $\left(\mathrm{C}^{0}\right)$} \\
\hline 5 & 2.739 & 3.440 & 28.023 \\
\hline 20 & 2.920 & 3.436 & 29.969 \\
\hline 60 & 3.120 & 3.340 & 30.320 \\
\hline 100 & 3.610 & 3.326 & 29.476 \\
\hline Sig. & $* *$ & $* *$ & $* *$ \\
\hline $\operatorname{LSD}(0.05)$ & 0.105 & 0.105 & 0.106 \\
\hline \multicolumn{4}{|l|}{ soaking period ( $\mathrm{hr}$ ) } \\
\hline 1 & 2.66 & 3.48 & 28.48 \\
\hline 3 & 2.82 & 3.48 & 29.53 \\
\hline 9 & 3.01 & 3.39 & 30.23 \\
\hline 18 & 3.27 & 3.24 & 30.23 \\
\hline 24 & 3.82 & 3.32 & 31.13 \\
\hline Sig. & $* *$ & $* *$ & $* *$ \\
\hline $\operatorname{LSD}(0.05)$ & 0.117 & 0.117 & 0.119 \\
\hline \multicolumn{4}{|l|}{ storage time (month) } \\
\hline 0 & 2.590 & 3.614 & 32.365 \\
\hline 2 & 2.626 & 3.458 & 30.702 \\
\hline 4 & 2.863 & 3.357 & 28.630 \\
\hline 6 & 3.344 & 3.329 & 28.610 \\
\hline 8 & 3.754 & 3.291 & 26.655 \\
\hline Sig. & $* *$ & $* *$ & $* *$ \\
\hline $\operatorname{LSD}(0.05)$ & 0.117 & 0.117 & 0.119 \\
\hline
\end{tabular}

2. The packaging type, cultivars of Roselle, extraction method soaking temperature, soaking period and storge time were highly significant effect for TSS, and anthocyanin, but there are no significant difference in $\mathrm{pH}$ value with packaging type or extraction method.

3. Higher total soluble solids content was recorded for dark red cultivar packaged in low density polyethylene (LDPE) and extracted with acidic water ( $2 \%$ citric acid) at $100 \mathrm{C}^{0}$ for $90 \mathrm{~min}$
4. The $\mathrm{pH}$ value of light roselle calyxes extract was less than that in dark red roselle calyxes extract for all treatments.

5. Anthocyanin value increased in roselle calyxes extracts of both dark and light cultivars with increasing soaking temperature and soaking period in both water or acidic water ( $2 \%$ citric acid) with used two packaging materiales and decreased with increasing storge period 


\section{REFERENCES}

Al-Kahtani, H. and Hassan, B.H. (1990) Spray drying of roselle (Hibiscus sabdariffa $\quad$ L.) extract. J. Food Sci.55(4): 1073-1076.

A.O.A.C. (2005) Offical Methods of Analysis of the Association of Official Analytical Chemsits $15^{\text {th }} \mathrm{Ed}$, Arlinton, Virginia USA.

Babalola, S.O., Babalola, A.0 and O.C.,Aworh (2000) Compositional attributes of the calyces of roselle (Hibiscus sabdariffa L.) . The Journal of Food Technology in Africa,6(4):133-134

Beristain ,C.L., R,E. Mendoza. H.S. Garcia, and A.Vazquez (1994) Cocrystallization of jamaica (Hibiscus subdariffa L.) granules. Academic Press Limited,347-379.

Bold, M.K. Oluwalan , I.B. and Ojo, O (2009) Commercial Practice of Roselle (Hibiscus sabdariffa L.) Beverage Production: Optimization of Hot Water Extraction and Sweetness Level . World Journal of Agricultural Sciences 5 (1): 126-131

Chumsri,P., Sirichote, A and Itharat,A. (2008) Studies on the optimum conditions for the extraction and concentration of roselle (Hibiscus sabdariffa Linn.) extract. Songklanakarin J. Sci. Technol. 30 (Suppl.1), 133-139.

Du, C. T. and Francis, F. J. (1973) Anthocyanins of roselle (Hibiscus sabdariffa, L). J. Food Sci., 38: 810-812.
Du , C.T., P.L. Wang and F.J.Francis (1975) Anthocyanins of Pomegranate, J.of Food Sci. 40(2) 417-418 J. Food Sci, Tech.A.7 No 8P8, 1143.

Farnworth, N.R. and Bunyapraphatsara, N. (1992) Thai Medicinal Plants. Prachachon Press, Bangkok.

Fasoyiro,S.B, Ashaye, O.A. Adeola, A. and Samuel, F.O. (2005) Chemical and Storability of Fruit-Flavoured (Hibiscus sabdariffa) Drinks. World Journal of Agricultural Sciences 1 (2): 165-168

Francis, F.J. (1985) Pigments and other colorants. In Food Chemistry, 2nd ed., Fennema, O. R. (Ed.), Marcel Dekker, Inc., New York and Basel, USA. p. 545-584.

Hirunpanich, V., Utaipat, A., Morales,N.P.,Bunyapraphatsara, N., Sato, H., Herunsale, A. and Suthisisang, C. (2006) Hypocholesterolemic and Antioxidant Effects of Aqueous Extracts form The Dried Calyx of Hibiscus sabdariffa L. in Hypercholesterolemic Rats. J. Ethno-Pharmacology., 103:252-260

Mazza, G. and Miniati, E.( 1993) Anthocyanis in Fruits, Vegetable, and Grains. CRC Press Inc., London, pp: 1-23.

Sato, K.Y.; K. Yoshihira, and H. Noguchi,(1991) Structure and contents of main coloring constituents in the calyxes of Hibiscus sabdariffa and commercial roselle color.J Food Hyg. Soc. Japan 32: 301.

Umerchuruba, C.I., (1997) An annotated list of plant diseases in Nigeria. Pen and Paper Publication, Owerri, Nigeria.

Wong, P.K., Yusof, S., Ghazali, H.M. and Man, Y.B.C. (2002) Physico-Chemical Characteristics of Roselle (Hibiscus sabdariffa L.). J. Nutr Food Sci., 32(2):68-73. 


\section{الملخص العربي}

\section{دراسة تأثير مواد التعبئة والتغليف وظروف التخزين والأصناف وطرق الاستخلاص على جودة مستخلص سبلات الكركدية}

$$
\text { رمزي بسيونى جمعة، ناهد مصطفى مُحَّمَ راشد }
$$

ووجد أن كمية المواد الصلبة الذائبة تزداد بزيادة درجة حرارة وزمن

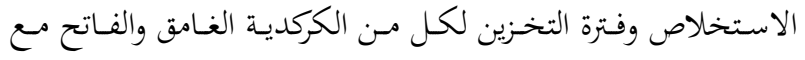

العبوات وطرق الاستخلاص تحت الدراسة. أيضا وجد أن أعلى كمية

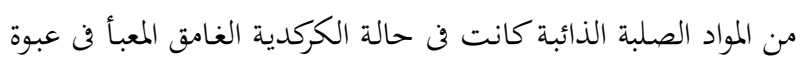

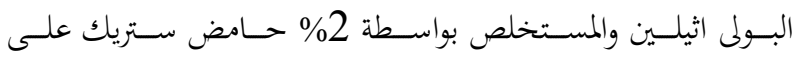

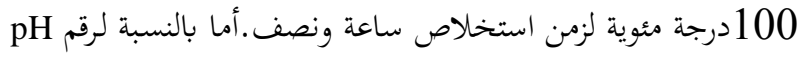

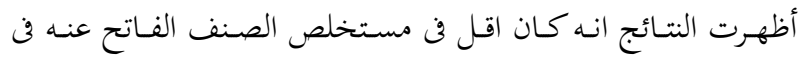

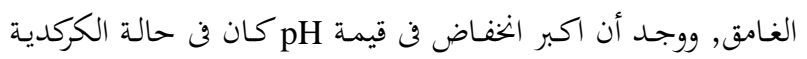

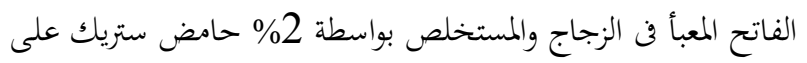
100درجة مئوية لزمن استخلاص ساعة ونصف.وبتقدير الانثوثيانين

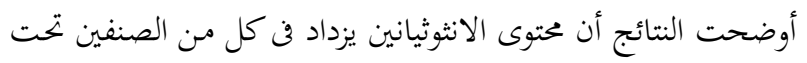

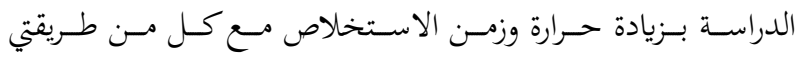
الاستخلاص والعبوات المستخدمة.

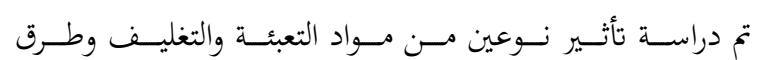
الاستخلاص وفـترة التخـزين على بعض صـفات الجمودة لمستخلص

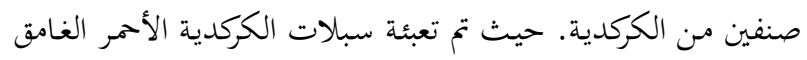

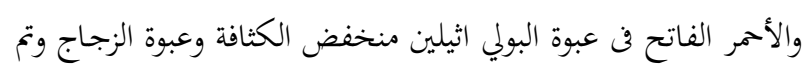

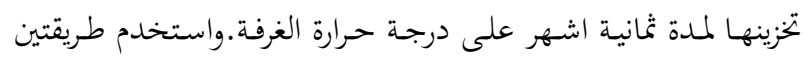

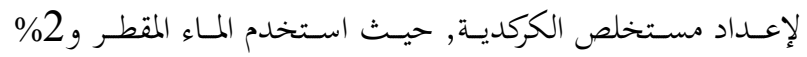
حامض ستريك على درجات حرارة 5,20,60,100 درجة مئوية

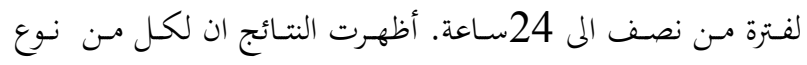
العبوة ونوع الصنف وطريقة الاستخلاص ودرجة حرارة الاستخلاص

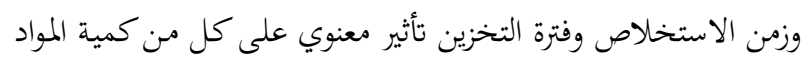

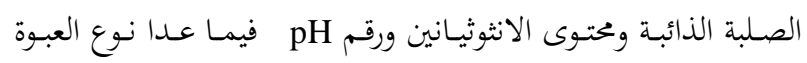
وطريقة الاستخلاص أوضحت النتائج أنة ليس لهم اى تأثير معنوى على رقم 